Int. J. Electrochem. Sci., 15 (2020) 5597 - 5608

International Journal of

ELECTROCHEMICAL

SCIENCE

$\underline{\text { www.electrochemsci.org }}$

\title{
Tuning the Activity and Stability of Platinum Nanoparticles Toward the Catalysis of the Formic Acid Electrooxidation
}

\author{
Islam M. Al-Akraa ${ }^{1}$, Bilquis Ali Al-Qodami ${ }^{2}$, Mysore Sridhar Santosh ${ }^{3}$, R. Viswanatha ${ }^{4}$, \\ Abdul Kareem Thottoli ${ }^{5}$, Ahmad M. Mohammad ${ }^{2, *}$ \\ ${ }^{1}$ Department of Chemical Engineering, Faculty of Engineering, The British University in Egypt, Cairo \\ 11837, Egypt \\ ${ }^{2}$ Chemistry Department, Faculty of Science, Cairo University, Cairo 12613, Egypt \\ ${ }^{3}$ Center for Incubation, Innovation, Research and Consultancy (CIIRC), Jyothy Institute of Technology, \\ Thataguni, Off Kanakapura Road, Bangalore -560082, Karnataka, India \\ ${ }^{4}$ Department of Chemistry, Jyothy Institute of Technology, Thataguni, Off Kanakapura Road, Bangalore \\ - 560082, Karnataka, India \\ ${ }^{5}$ Department of Physics, PSMO College, Tirurangadi, Malappuram, Kerala 676306, India \\ *E-mail: ammohammad@cu.edu.eg
}

doi: $10.20964 / 2020.06 .81$

Received: 18 January 2020 / Accepted: 4 April 2020 / Published: 10 May 2020

The impact of tuning the electrodeposition potential $\left(E_{\mathrm{Pt}}\right)$ of platinum nanoparticles (PtNPs) on the catalytic activity and stability of PtNPs-modified glassy carbon (GC) (Pt/GC) catalysts toward the formic acid electro-oxidation (FAO) was electrochemically examined. Practically, different potentials $\left(E_{\mathrm{Pt}}=-0.20,-0.10,0.00,0.10\right.$ and $\left.0.20 \mathrm{~V}\right)$ comprising the underpotential and overpotential deposition domains of PtNPs were employed while passing the same coulombic charge $(10 \mathrm{mC})$ which ensured the deposition of the same loadings of PtNPs. The investigation disclosed the critical role of the deposition potential of PtNPs in the Pt/GC catalyst on justifying not only the catalyst's activity toward FAO which appeared boosted largely at the border potentials $\left(E_{\mathrm{Pt}}=-0.20\right.$ and $\left.0.20 \mathrm{~V}\right)$ but also the catalyst's stability which owned the highest durability at $0 \mathrm{~V}$. Several indices utilizing the current densities of the direct (favorable dehydrogenation) oxidation peak $\left(I_{\mathrm{p}}^{\mathrm{d}}\right)$, the indirect (unfavorable dehydration - poisoning) oxidation peak $\left(I_{\mathrm{p}}{ }^{\text {ind }}\right)$ and the backward oxidation peak $\left(I_{\mathrm{p}}{ }^{\mathrm{b}}\right)$ in the cyclic voltammetry of FAO were utilized to assess and compare the catalytic efficiencies of the catalysts. Interestingly, for the Pt/GC catalyst $\left(E_{\mathrm{P}}=0.2 \mathrm{~V}\right)$, the $I_{\mathrm{p}}{ }_{\mathrm{d}}^{\mathrm{d}} / I_{\mathrm{p}}{ }^{\text {ind }}$ ratio was 8 which reflected the preference of the FAO's mechanism to proceed via the favorable dehydrogenation pathway, while the $I_{\mathrm{p}} \mathrm{d} / I_{\mathrm{p}}{ }^{\mathrm{b}}$ ratio was 0.77 which, moreover, highlighted the high tolerance of the catalyst for $\mathrm{CO}$ poisoning. While the catalytic enhancement of FAO was predominantly electronic at $-0.20 \mathrm{~V}$, it presumably originated geometrically at $0.20 \mathrm{~V}$; as revealed from the electrochemical impedance spectroscopy.

Keywords: Formic acid electro-oxidation; Pt nanoparticles; Electrodeposition potential; Fuel cells. 


\section{FULL TEXT}

(C) 2020 The Authors. Published by ESG (www.electrochemsci.org). This article is an open access article distributed under the terms and conditions of the Creative Commons Attribution license (http://creativecommons.org/licenses/by/4.0/). 